\title{
Study of Cultural Value of Jingdezhen Rose Porcelain Art in International Exchange from the Perspective of Globalization
}

\author{
Weifang Ke \\ School of Ceramic Art \\ Jingdezhen Ceramic Institute \\ Jingdezhen, China 333403
}

\author{
Xiaosong Zou \\ School of Ceramic Art \\ Jingdezhen Ceramic Institute \\ Jingdezhen, China 333403
}

\begin{abstract}
With the literature method, survey method and correlation method, the paper has researched the cultural value of Jingdezhen rose porcelain art under the background of globalization. Now the western culture occupies a dominant position. The paper has analyzed the possibility, necessity and urgency to enhance foreign exchange of Jingdezhen rose porcelain art in order to increase our discourse power and international competitiveness on culture. The paper has summed up the cultural value of its foreign exchange, and explored effective ways to improve the communication ability of Jingdezhen rose porcelain art.
\end{abstract}

Keywords-globalization; rose porcelain art; foreign exchanges; cultural value

\section{INTRODUCTION}

Civilization is derived from the unique achievement under certain historical and cultural traditions and geographical natural environment. Culture is a specific manifestation of this achievement. Therefore, culture has differences, nationalism, regionalism and universality. First of all, the special achievements of all ethnic countries are part of the human civilization, and have certain universality. It is precisely because of this universality that the possibility of communication and exchange among countries is determined. Secondly, with different time and space backgrounds, the objective existence of the unique achievements of various nationalities and countries determines the necessity of intercultural communication and exchange [1]. In short, the complementary nature of cultural universality and individuality is the foundation of cultural communication and exchange. The progress of human civilization calls for intercultural communication and exchange.

China is an ancient civilized country with a long history. It occupies a very important position in the world culture, and has created a number of material cultural relics and spiritual cultural heritages which has attracted worldwide attention. As a typical representative, the ceramic art culture

Fund project: 2017 Annual National Fund for Talent Training and Innovation of Rose Porcelain Art; Project No.: 2017-A-04- (125) -0639; 2016 Annual Cultural Arts and Science Planning Project of Jiangxi Province; Project No.: YG2016055I. has the dual attributes of material culture and spiritual culture. In the early Neolithic age, Chinese ancestors invented pottery technology, creating the world-famous "Pottery Civilization", which makes China become one of the first counties to produce and use pottery. In the middle of the Shang Dynasty, China succeeded in burning out the original porcelain. In the Eastern Han Dynasty, China invented the porcelain in the real sense. In view of this, Chinese ceramic technology has become a great miracle in the history of world arts and crafts. China's ceramic culture has been communicating, exchanging, colliding and merging with the world's ceramic culture since ancient times. The Chinese ceramic culture has learnt strong points from the western art, and been scattered, reconstructed, fused, inherited and innovated, and created the excellent Chinese ceramic culture. Since the Tang Dynasty, China's inclusive and open foreign policy has provided a valuable opportunity for the exchange of ceramic culture to the outside world, and China's ceramics have been sold to a lot of countries in the world. Its excellent porcelain-making technology and brilliant artistic achievements have had a profound impact on ceramic production in many countries, and strongly promoted the development of world ceramic culture. For example, the tri-colored glazed pottery of the Tang Dynasty has been very famous around the world. It has absorbed excellent foreign culture and built a unique style of coloredpottery art of Tang Dynasty. The blue and white porcelain art of Yuan Dynasty has been exported to overseas countries. In the Ming Dynasty, Zheng He traveled to the West for seven times and made exchanges with African countries. All these historical facts, including the famous "Silk Road" and "Maritime Silk Road", have witnessed the glorious tradition of the Chinese nation and our inclusive and open attitude to foreign exchange. The glorious history of Chinese ceramic culture will inspire us to forge ahead. In the new period, we will positively response to the national "the Belt and Road" strategy, for it has very important practical significance to strengthen the foreign exchange of China's ceramic culture.

Rose porcelain art was originated in the Kangxi period of the Qing Dynasty. On the basis of Kangxi colored technology, our ancestors combined technical characteristics of western enamel and successfully burned it and developed 
it. It was a crystallization of cultural exchanges with Western art. It has common genes of Eastern and Western art. Rose porcelain art has natural kinship with exotic enamel, so it has inherent affinity with foreign exchange, and is loved by domestic and international collectors. It can communicate with the western culture and arts without barrier, so it has important cultural value in foreign exchange. Many famous foreign art museums have been proud of having collection of Jingdezhen rose porcelain. From the Qing Dynasty to modern and contemporary society, rose porcelain, often as a representative of characteristic culture, are given to foreign dignitaries and diplomats. The seamless grafting of Kangxi colored porcelain with enamel has strong flavor of Chinese characteristics. After clearing up, fusing and shaping, it became a new porcelain art - rose porcelain. It has realized the purpose of "taking the essence and discarding the dross" and "making foreign things serve China". It is an innovative model of Chinese ceramic art basing on ourselves and learning from the West. It is also a good way to inherit and spread our excellent culture of Chinese characteristics and strengthen our discourse power and cultural soft power in world culture in our current strategic deployment of "the Belt and Road" and under the background of accelerating globalization. Jingdezhen rose porcelain art, as the crystallization of cultural exchanges between China and Western countries, plays a very important role in the foreign exchange.

\section{The Cultural VAlue of Jingdezhen Rose PORCELAIN ART IN FOREIGN EXCHANGE}

\section{A. The Need to Provide a Stable and Harmonious} International Environment to Enhance Cultural

\section{Confidence and to Achieve a Great Rejuvenation of the} Chinese Nation

First of all, with no a high degree of cultural confidence, there will be no prosperity of culture and no great rejuvenation of the Chinese nation. Cultural confidence is a basic, deep and lasting power of a nation in the development [2]. The historical achievements of culture and the excellent spirits, ideas and concepts in it are the cornerstones of cultural confidence of the Chinese nation. Secondly, realizing the Chinese dream is inseparable from the understanding and support of the international environment. It is a basic need to continuously enhance China's dominant and discourse power in the international ideology, build Chinese spirits, Chinese values and create a favorable international environment to realize the Chinese dream. Thirdly, rose porcelain art is the crystallization of cultural communication with Western art. It has common genes of Eastern and Western art. It can overcome the language barrier, and play an incomparable advantage in international communication and exchanges. In addition, its specific form of language and implied connotation can bring people a wonderful sensual enjoyment. One sees it as if facing a mild braze. It has an appeal to one's heart and can get extensive international identity. It gets twice the result to tell Chinese story, spread Chinese voice, demonstrate Chinese characteristics and show Chinese image well, and spread excellent Chinese thoughts by using this art in foreign exchange. It can be a lubricant or a bridge in foreign relations. It can provide a favorable international environment for the great rejuvenation of the Chinese nation.

\section{B. The Need to Strengthen the National Cultural Soft Power and Improve the International Competitiveness of the Culture}

Culture is the soul of a nation and an inexhaustible motive for its development. Today's international competition has risen to the competition of cultural soft power, which is the competition of international discourse power and international influence. The exchange and blending and confrontation of different cultures intensify currently. It is urgent to actively carry out cultural communication to outside world, make efforts to mine the essence of Chinese culture, inherit and spread our excellent culture in order to become a world cultural power. Traditional Jingdezhen rose porcelain art is a representative symbol of excellent ethnic culture. It's valuable to constantly excavate its cultural connotation, innovate its forms and contents, explore the exchange and collision of ceramic art with the West, and thus form a comprehensive international ceramic art exchange system. For example, held overseas exchange exhibition of rose porcelain art to show characteristics and exquisite craftsmanship of Chinese rose porcelain art and highlight modern rose porcelain artist's thoughts on past and modern conflict and integration. It can open a door for foreigners to know, care and understand Chinese ceramic art and Chinese culture, and make a contribution to the improvement of competiveness of Chinese vulture and the communication of Chinese ceramic culture.

\section{The Need to Actively Integrate into the National Strategy of "The Belt and Road", and Promote and Carry forward Chinese Ceramic Culture}

The General Offices of the CPC Central Committee and the State Council issued "Opinion on the Implementation of the Excellent Traditional Chinese Culture Inheritance and Development Project". It pointed out: "strengthen cultural exchange and cooperation with countries along "the Belt and Road", encourage the development of cultural trade, enabling more cultural products representing Chinese cultural characteristics with strong competitiveness flow into the international market. The exchange of Chinese ceramic culture has a glorious history. Ancient China has ever spread our ceramic culture to countries in Asia and Europe and the United States through "Silk Road" and "Maritime Silk Road" (also known as "Porcelain Road"), writing a glorious chapter in the history of human civilization. The rose porcelain was successfully burnt by learning from the exotic enamel in the Kangxi period of the Qing Dynasty. The full implementation of "the Belt and Road" strategy has provided a new historical opportunity for international communication of Jingdezhen rose porcelain art culture. With this precious opportunity, we should "tel Chinese story, spread Chinese voice and show Chinese spirits well" along the road with the form of rose porcelain 
art culture [3]. For example, actively integrate into the strategy of "the Belt and Road". Jingdezhen Ceramics University has held ceramic art exhibitions in the headquarters of UNESCO, the Le Louvre Museum in France, University of Cambridge, Greece Asia Museum and other important places, which fully showed the charm of Chinese ceramic culture and promote the spread of rose porcelain around the world. Actively absorb excellent fruits of other civilizations and make contribution to the promotion and inheritance of Chinese ceramic culture.

\section{The Need to Make a Famous Brand out of A Rose Porcelain Art, and a Worldwide Ceramic Culture Exchange Center out of a Millennium Porcelain City}

Jingdezhen has made outstanding contributions in the world porcelain-making history. It has accumulated rich ceramic culture and resources. It has a Millennium porcelain history. Jingdezhen ceramic culture is an outstanding representative of world ceramic culture. Contemporary Jingdezhen is world famous city in ceramic culture. It is branded by handmade porcelain and innovative ceramic culture. Jingdezhen shall undertake the responsibility to develop traditional Chinese ceramic culture and make a glory in ceramic culture, and make a worldwide ceramic culture exchange center out of a Millennium porcelain city, contributing to foreign exchange of Chinese ceramic culture. For example, the International Ceramics Expo, held by the Ministry of Commerce, China Council for the Promotion of International Trade, China Light Industry Association and Jiangxi Provincial People's Government in Jingdezhen every year, not only shows Jingdezhen ceramic culture to the world, but also build an important international and professional ceramic culture exchange platform, promoting the dialogue between Jingdezhen and the world.

Jingdezhen rose porcelain is one of four famous porcelains. The rose and soft color and its exquisite craftsmanship and elegant style make it well-known around the world. As an important part of splendid Chinese ceramic art, rose porcelain art has been the main stream since the Qing Dynasty. With fresh and elegant art style, it has the good fame of "the Pearl of the Oriental Art". No matter in the past, now or in the future, its value of times is never fading. The glorious history and unique symbol attribute of rose porcelain art make it become a brand in world ceramic cultural exchange. For instance, Ning Gang, President of Jingdezhen Ceramics University, has ever given a rose porcelain vase Xiang $\mathrm{He}$ and a rose porcelain plate Suisui Hehe to British Queen who collected them in the Buckingham Palace; the APEC summit in Beijing has presented two rose porcelain vase Suisui Hehe and Suisui Ping 'an in the main conference hall.

\section{WAYS TO ENHANCE THE COMMUNICATION ABILITY OF ROSE PORCELAIN ART IN FOREIGN EXCHANGE}

Different ideologies and cultures result in different reading perspective and value judgment. We still face constraints and challenges in the foreign exchange of our rose porcelain art. It is an effective way to actively seek countermeasures, and strive to explore a breakthrough, and make spread path, angle and methods of rose porcelain art diverse.

First, strengthen the construction of curatorial personnel, improve the curatorial ability of Chinese art culture, and constantly improve the exchange level of rose porcelain culture. Second, actively build a professional spread platform led by China, fully displaying the charm of Chinese rose porcelain in a diversified, multi-level, allround way. As methods of the international cultural exchange are increasingly diversified, we can make full use of the platforms of the dominant Chinese Culture Center, festival exhibitions, cultural relics exhibitions and expos. Abiding by the approach of "knowing both your opponent and yourself, observing the customs of the place, adhering to our position and expressing in an international way", we can fully display the international value of our rose porcelain art culture. In addition, it can expand space for the spread of Chinese excellent culture, enable more foreigners to enjoy the appreciation process, and let the excellent traditional culture of the Chinese nation shine in the international stage [4]. Last, explore a new model for international communication and exchange of rose porcelain art, comprehensively use methods of mass communication, group communication, interpersonal communication, especially the popular multimedia communication platforms, including Internet, micro-blog and WeChat, with voice, video, images, text and other forms, for they have the advantages of fast spread, wide coverage, high efficiency and good interaction [5]

\section{CONCLUSION}

- Jingdezhen rose porcelain art has common genes of Eastern and Western art for it combines the technology of western enamel on the basis of Kangxi colored porcelain. It has possibility, necessity and urgency to enhance foreign exchange of Jingdezhen rose porcelain art in order to increase our discourse power and international competitiveness on culture as the Western culture occupies a dominant position in the globalization.

- Jingdezhen rose porcelain art has cultural value in foreign exchange. It is the need to provide a stable and harmonious international environment to enhance cultural confidence and to achieve a great rejuvenation of the Chinese nation, the need to strengthen the national cultural soft power and improve the international competitiveness of the culture, the need to actively integrate into the national strategy of "the Belt and Road", and promote and carry forward Chinese ceramic culture, and the need to make a famous brand out of a rose porcelain art, and a worldwide ceramic culture exchange center out of a Millennium porcelain city.

- The effective ways to improve spread ability of Jingdezhen rose porcelain: first, strengthen the construction of curatorial personnel, and improve the curatorial ability of Chinese art and culture. Second, actively build a professional spread platform 
dominated by China and expand space for spread of Chinese rose porcelain art. Third, explore the new mode for international communication of rose porcelain art culture, and comprehensively various communication channels, especially the multimedia communication platforms, including Internet, microblog and WeChat, for they have the advantage of fast spread, wide coverage, high efficiency and good interaction, forming an all-round, multi-dimensional communication pattern.

\section{REFERENCES}

[1] Chen Dazheng. Communication Culture. Wuhan: Central China Polytechnic University Press, 1996 edition.

[2] Xi Jinping. Report of the 19th National Congress of CPC. October 18th, 2017.

[3] The general offices of the CPC Central Committee and the State Council. Opinions on Implementation of Inheritance and Development of Excellent Traditional Chinese Culture Project. Beijing: Xinhua News Agency, January 25, 2017.

[4] Wang Ying. Cultural Confidence and the International Communication of Excellent Traditional Chinese Culture. Guangdong Social Science, 5 Issue, 2017.

[5] Ke Weifang, Gu Haodong, Huang Sheng. Multimedia Technology in Propaganda of Ceramic Creative Culture. Arts Appreciation, 11 Issue, 2015 . 